\title{
Is ESG Relevant to Electricity Companies during Pandemics? A Case Study on European Firms during COVID-19
}

\author{
Florin Teodor Boldeanu ${ }^{1, *}, \mathbb{C}$, José Antonio Clemente-Almendros ${ }^{2}$, Ileana Tache ${ }^{3, *}$ \\ and Luis Alberto Seguí-Amortegui ${ }^{2}$ (i)
}

1 Department of Finance, Accounting and Economic Theory, Faculty of Economic Sciences and Business Administration, Transilvania University of Brasov, 500036 Brașov, Romania

2 Business and Communication Faculty, International University of La Rioja, 26006 Logroño, Spain; joseantonio.clemente@unir.net (J.A.C.-A.); luisalberto.segui@unir.net (L.A.S.-A.)

3 Department of Marketing, Tourism-Services and International Business, Faculty of Economic Sciences and Business Administration, Transilvania University of Brasov, 500036 Brașov, Romania

* Correspondence: florin.boldeanu@unitbv.ro (F.T.B.); ileanatache@unitbv.ro (I.T.)

\section{check for}

updates

Citation: Boldeanu, F.T.;

Clemente-Almendros, J.A.; Tache, I.; Seguí-Amortegui, L.A. Is ESG Relevant to Electricity Companies during Pandemics? A Case Study on European Firms during COVID-19. Sustainability 2022, 14, 852. https:// doi.org/10.3390/su14020852

Academic Editors: Asma Mobarek, Kais Bouslah, Qian Li and Carlos Rodríguez Monroy

Received: 28 November 2021

Accepted: 10 January 2022

Published: 12 January 2022

Publisher's Note: MDPI stays neutral with regard to jurisdictional claims in published maps and institutional affiliations.

Copyright: (c) 2022 by the authors. Licensee MDPI, Basel, Switzerland. This article is an open access article distributed under the terms and conditions of the Creative Commons Attribution (CC BY) license (https:/ / creativecommons.org/licenses/by/ $4.0 /)$.

\begin{abstract}
The electricity sector was negatively impacted by the coronavirus disease (COVID-19), with considerable declines in consumption in the initial phase. Investors were in turmoil, and stock prices for these companies plummeted. The aim of this paper is to demonstrate the significant negative influence of the pandemic on abnormal returns for the electricity sector, specifically for traditional and renewable companies and the influence of ESG scores, using the event study approach and multi-variate regressions. Our results show that the pandemic indeed had a negative impact on the electricity sector, with renewable electricity companies suffering a sharper decline than traditional ones. Moreover, we find that ESG pillar scores affected electricity companies differently and are sector-specific. For renewable electricity companies, the returns were positively influenced by the environmental ESG scores and negatively by governance ESG scores.
\end{abstract}

Keywords: ESG scores; COVID; electricity companies; market returns

\section{Introduction}

On 11 March 2020, the World Health Organization (WHO) (Geneva, Switzerland) declared COVID-19 a worldwide pandemic. Even though the crisis created by the pandemic influenced the global economy, particularly financial markets [1], COVID-19 represents an unprecedented situation. It not only had a direct impact on the economy, the mobility of people and goods, electricity consumption, and investors' confidence [2], it also had a significant negative impact on short-term financial market profitability [3]. The economic and financial crisis created by the COVID-19 pandemic represents a unique framework toward understand financial market responses to a global crisis [4].

Nevertheless, the effect of the COVID-19 pandemic crisis was not similar for all sectors. Depending on their vulnerability to the effects of the pandemic, there were different and opposite sectorial impacts [5]. Even with extensive empirical evidence, in the literature, on the impact of COVID-19 on financial markets [6-8], sectorial analysis is still scarce [9], and a deeper analysis is needed $[10,11]$. As far as we are aware, this is the first paper that focuses on differences in the impact of COVID-19 on the electricity subsectors in Europe, comparing the impact of the pandemic on renewable and traditional electricity, together with the influence of environmental, social, and governance (ESG) scores.

One approach to corporate social responsibility (CRS) comes from Sheehy [12]: “a socio-political movement which generates private self-regulatory initiatives, incorporating public and private international law norms seeking to ameliorate and mitigate the social harms of and to promote the public good by industrial organizations". Considering the broad scope of this definition of CRS, which brings to the forefront the interest of 
shareholders and stakeholders, an accepted metric to measure CRS activities is the ESG score $[13,14]$.

In some of the literature, researches have analysed the impact of ESG factors on stock market returns [15], and its influence in the COVID-19 pandemic context [16].

Investors may indeed be influenced by companies' CRS policies when it comes to including or excluding companies in their investment portfolios, since they respond to the information released by ESG indicators and pressure companies to adopt ESG transparency [17]. ESG reports aim to be a source of information used for screening investment decision-making [18]. Even though there is growing interest in knowing whether the information given by ESG indicators is a leading factor on equity prices or returns, the debate is open in the literature about the relationship between ESG factors and financial performance, more specifically on how the different components of ESG indicators are priced into financial market equities, and over what specific time period [19]. The evidence in the literature is not conclusive, with some either in favour of the positive effect of ESG indicators on a firm's value and performance [20,21], or against this positive influence [22,23]. Moreover, some authors claim that the influence of ESG indicators is context- and sector-specific [24-27]. Thus, we aim to shed light on this puzzling evidence, going in detail $[22,28,29]$, via a deeper analysis of the different ESG pillar scores to find which factor (environmental, social, or governance) may have the largest influence. In addition, our paper belongs to the few cohorts that study the effect of ESG information and specific industries, such as clean technology [30] and environmental corporate policies and performance in specific industries [31].

This study analyses the heterogeneous behaviour of the electricity industry, distinguishing between two ways of producing electricity-renewable and traditional. Our study focuses on the European framework because of the increasing importance of renewable electricity in Europe, determining the continent, to focus more on the production of electricity from renewable sources than fossil fuels. Moreover, even though Europe leads when it comes to sustainable ways of producing electricity, it is an energy importer area as compared to countries such as Russia [32]. More notably, the European financial market proved to be more susceptible to COVID-19 events, with a larger stock market volatility [6]. Then, the paper shows that the effects of the COVID-19 crisis were not homogeneous, demonstrating the impact according to specific sectorial characteristics. More specifically, we clarify how the effects of the pandemic were different, due to different risk profiles of renewable and traditional energy, and how these different effects were due to the specific information conveyed in the three ESG pillar scores.

In this paper, we study the stock price response of listed companies to COVID-19 effects in the European utility sector, and the influence of ESG scores on that response. Specifically, we analyse its effect on electricity utilities in Europe (traditional production and distribution of electricity, including nuclear and non-nuclear), and on the alternative sustainable renewable electricity producers. It is obvious that renewable energy shows substantial growth, representing almost one-third of worldwide energy, becoming a crucial energy sector [2,33]. However, this strategic sector depicts specific characteristics and risks, resulting in important return volatility and institutional and policy dependence $[34,35]$.

We considered the differences between electric utilities and renewable electricity producers. Next, we estimated the cumulative average abnormal returns (CAARs) from the announcement of the pandemic by the WHO (11 March, 2020). Then, we compared the impact of these two specific announcements on the stock prices of both types of electricity production companies in European countries. The empirical evidence from the literature confirms that information from COVID-19 indicators play a significant role in spillover effects of financial markets and changes in the market structure of the energy sector [36]. We used the event study approach to analyse the stock market reactions to both specific events, using the Fama-French three-factor model $[37,38]$. Finally, we used multivariate regressions to check the influence of ESG factors during the COVID-19 pandemic crisis on the traditional and renewable European electricity companies. 
First, we showed that the general electricity sector, more specifically, traditional and renewable subsectors, had negative CAARs during the pandemic. We found that for renewable electricity firms, the returns were positively influenced by the environmental and social ESG scores, as these companies are more involved in environmental and social disclosure procedures compared to traditional electricity companies. The environmental score had a negative impact on traditional electricity companies and the governance score a positive impact. Moreover, efforts related to environmental activities for traditional electricity companies did not have a direct impact on financial performance.

Our study contributes to the literature as follows. First, we confirm the negative impact of the COVID-19 crisis on European electricity companies as a whole, and for the traditional and renewable sectors. We show that renewable companies were more affected. Our results reveal the heterogeneous characteristics of both types of electricity. Secondly, we shed light on the debate on the importance and influence of ESG factors. We analysed the three main pillars of ESG scores in order to check whether there was a relationship between the information conveyed by the different ESG pillars and the type of sectors. Our results show that ESG scores are sector- and context-specific.

In the next section, we discuss the theoretical background regarding the different types of energy and ESG scores. In the Data and Methodology section, we present the data used in our study and the methodology. The empirical results are shown in the Results section. In the final section, we present the conclusions of the study.

\section{Literature Review}

There is a large body of literature on the influence of different pandemics (such as H1N1, Ebola, SRAS, DENGUE FEVER) on stock markets [1,39-42]. However, this impact shows sectoral differences $[43,44]$.

The economic and financial characters of the crisis generated by COVID-19 resulted in general uncertainty, political, economic, and financial difficulties. In particular, the impact was notable for investors' confidence, increasing stock market risks and volatility, and negative returns [45-47].

Nonetheless, the effect of the COVID-19 pandemic was not similar in all sectors [48-51]. Ramelli and Wagner [52] found that stock prices of the transport and energy sectors were affected negatively by COVID-19. Shahzad, Bouri, Kristoufek, and Saeed [53] showed that the energy sector suffered from significant profit downturns. He, Sun, Zhang, and Li [5] concluded that some sectors showed endurance capacity to the pandemic, but others, such as the electricity sector, were negatively affected.

The energy sector suffered from a higher risk perception during the COVID-19 pandemic. The COVID-19 crisis had an influence on the energy market structure [36,54]. COVID-19 has shown the importance and influence of electricity in our economy, financial markets, and society [55]. However, even though this sector has been strongly affected by the pandemic since the consumption of electricity decreased at record levels [56], the effects of different types of energy are not so obvious. It is crucial to understand how to prevent future crises and to identify and reveal possible opportunities [57]. Moreover, this unique pandemic has shown the importance of governmental interventions, regulations, and policies [58]. In the framework of the decarbonisation process meant to prevent climate change, renewable energy plays a strategic role, with an increasing importance of this type of energy on electricity markets [59]. In Europe, in the context of the Clean Energy Transition program, renewable energy has overtaken fossil-based electricity in 2020. Due to the exposure of Europe to the uncertainty of the global economy [60], and the special sensitivity shown by the European markets [61], companies adjusted their expectations, affecting market volatility [62]. Understanding the energy sector and its different characteristics and risk behaviours of the alternative types of energy has become strategic, since in Europe there coexists traditional and renewable ways of producing energy [32], and the strategic decisions made by European countries, in favour of decarbonization in the electricity industry, are clear. Specifically, the energy sector is associated with a risky investment. It is 
weather dependent, presenting uncertainty concerning the reliability of the supply [63], and casting doubts on the returns [64]. Moreover, institutional support of this sector is well known, such as the governmental economic compensation mechanism [65]. Additionally, this type of investment requires substantial capital investment, showing possible problems in financially breaking-even [66]. Its high volatility makes it difficult to hedge against [67]. We expect that COVID-19 negatively impacted the energy sector in our sample, and for this impact to be more negative for renewable companies. With this in mind, we formulated the following hypotheses:

Hypothesis 1a (H1a). The WHO announcement regarding the COVID-19 pandemic negatively affected the listed electricity European companies (in terms of cumulative abnormal returns).

Hypothesis $\mathbf{1 b} \mathbf{b} \mathbf{H 1 b})$. The WHO announcement regarding the COVID-19 pandemic negatively affected, to a greater extent, renewable electricity companies, compared to traditional electricity European companies (in terms of cumulative abnormal returns).

For a better understanding of the different behaviours of the energy sectors, we add EGS factors to this debate. There is growing evidence, in the literature, supporting the idea that E, S, and G scores may affect a firm's value, in a manner that decision-makers should no longer neglect [22]. There is a growing agreement that ESG factors correlate with a company's performance [19]. Thus, good performance (high ESG factors) is associated with a lower cost of debt and equity funding, which reduce volatility and, thus, risk, increasing a company's valuation and share price and facilitating better access to finances, resulting in higher operating efficiencies [22,23]. Equity markets can anticipate future outcomes related to future bad expected news and future costs for companies with low ESG factors [68]. Kruger [42] analysed the reactions of stock markets to different positive and negative ESG issues, showing evidence about investors reacting to these events; these reactions are stronger for negative events. Capelle-Blancard and Petit [22] showed that a sectoral ESG reputation lessens losses for the market value of companies. However, the debate is still open in this regard [69]. Orlitzky [23] argued that information conveyed by ESG factors only generates noise, because, among other reasons, it results from managerial opportunism.

However, context and external factors should be analysed, since the response to events and ESG is context-specific, being inconclusive from the empirical evidence [19]. The event study literature shows that negative external news is correlated with abnormal negative returns, being more robust for short-term event studies [70]. Sabbaghi and $\mathrm{Xu}$ [24] did not find a difference in terms of risk-return between companies with or without high ESG values in the post-financial crisis period. Mitsuyama and Shimizutani [25] did not find any reaction for the Japanese equity market for news from firms branded ESGs. Contrary to Japan, the European market is a more sensitive framework in relation to ESG issues. Sassen, Hinze, and Hardeck [26] concluded that European company risks are reduced by ESG or similar ratings. Cellier and Chollet [71] found a positive effect of these types of ratings and abnormal returns.

In this regard, there is inconclusive evidence about the influence of ESG factors during the COVID-19 pandemic. There is evidence in favour of ESG factors mitigating the financial risks and associated positively with excess returns during the crisis created by the COVID19 outbreak [13], and higher returns and lower volatility for firms with high ESG scores [72]. However, there is also evidence against this positive effect. Demers, Hendrikse, Joos, and Lev [14] did not find significant effects of ESG factors on market returns during the pandemic. In addition, Tampakoudis, Noulas, Kiosses, and Drogalas [73] found negative effects of ESG factors on shareholder wealth, before and during the COVID-19 crisis, being stronger during the pandemic. They suggest that, during the crisis created by the pandemic, sustainable activity costs could outweigh potential gains, concluding that ESG involvement may not be a resilience factor in such a crisis context, since ESG activities are 
costly investments, against the literature stating the potential resilience of ESG factors in the context of uncertainty [14,72].

This contradictory evidence suggests that we know little about this relation to ESG issues for a firm's value, and we must go in detail to understand it. In this line, we cannot find in the literature clear evidence on what factors (environmental, social, or governance) may have the largest impacts $[22,28]$. We take a position in favour of the literature that suggests that the influence of $\mathrm{E}, \mathrm{S}$, and $\mathrm{G}$ factors may be different, being affected by the specific context [22,28], and explaining the (sometimes-confusing) empirical evidence. We have developed the following hypotheses:

Hypothesis 2a (H2a). The environmental pillar score positively affected the listed electricity European companies, in terms of abnormal cumulative returns, during the COVID-19 pandemic.

Hypothesis $\mathbf{2 b} \mathbf{b} \mathbf{H} \mathbf{2 b})$. The social pillar score positively affected the listed electricity European companies, in terms of abnormal cumulative returns, during the COVID-19 pandemic.

Hypothesis 2c (H2c). The governance pillar score positively affected the listed electricity European companies, in terms of abnormal cumulative returns, during the COVID-19 pandemic.

Moreover, there is evidence that the effect of ESG factors on a firm's performance is contingent to certain sectors and the firm's strategy [27]. The analysis of investments and the comparison of different portfolios of securities need specific industry ESG scores that provide information about specific problems, styles, and strategies [74]. ESG information may be important for investment performance and decision-making, but this information varies systematically among industries (there are sectors more sensitive to environmental issues) and geographical areas (such as Europe, where the European energy transition is a strategic pillar) [21]. In that vein, we focused on the differences concerning the impact of the COVID-19 pandemic on the electricity subsectors in Europe and analysed the influence of ESG scores on renewable and traditional electricity firms. Then, we reformulated our $\mathrm{H} 2$ hypotheses and adapted them to the energy sector in Europe, in the context of the COVID-19 pandemic, on the belief that the influences of ESG pillars are context-dependent:

Hypothesis 3a (H3a). The environmental pillar score positively affected the listed renewable electricity European companies, in terms of abnormal cumulative returns. This pillar had a positive moderation effect on renewable electricity companies.

Hypothesis $\mathbf{3 b} \mathbf{b} \mathbf{H} 3 \mathbf{b})$. The social pillar score positively affected the listed renewable electricity European companies, in terms of abnormal cumulative returns. This pillar had a positive moderation effect on renewable electricity companies.

Hypothesis 3c (H3c). The governance pillar score positively affected the listed renewable electricity European companies, in terms of abnormal cumulative returns. This pillar had a positive moderation effect on renewable electricity companies.

\section{Data and Methodology}

The goal of this paper is to evaluate the role of ESG on market returns of electricity companies in Europe during the unique event represented by the COVID-19 pandemic. The investigation involved a quantitative analysis of the impact of environmental, social, and governance indicators during the negative event (a worldwide pandemic), using financial data (revenue, market capitalization, and beta) denominated in euros and a scale index for the ESG scores. In this research, firstly we calculated CAARs for the electricity companies to check the impact of COVID-19 in this sector and then for the two different ways of producing electricity (traditional and renewable). Next, using firm cumulative abnormal returns (CARs) as dependent variables, we checked the different influences of every ESG pillar for the abnormal returns, as a consequence of the pandemic, as well as the different 
impacts on traditional and renewable sectors. Moreover, via the interaction method, we show that the influence of ESG pillars is sectoral contingent.

The sample used in our research was obtained from Thomson Reuters Refinitiv EIKON to identify the existing electric utilities, and traditional and renewable electricity companies in Europe, with a total of 378 companies. Thomson Reuters Refinitiv EIKON is used extensively in the literature to show the importance of ESG ratings related to financial and non-financial indicators, and it is one of a few providers of these scores [14,73]. We consider it to, generally, be in the right place, for a deep dive into the financial world, and it a leading platform used by finance practitioners and researchers. Based on the Global Industry Classification Standard (GICS) [33], we extracted companies with the codes 55101010, 55105010, and 55105020. The first two codes are traditional electricity producers, whereas the latter corresponds to renewable electricity producers. We used the adjusted daily price for each company in order to see the net effect of the pandemic not affected by dividends [75]. A validation process was conducted to compare the data from Refinitiv EIKON to other providers, such as the Osiris database, Yahoo Finance, and investing.com. Finally, we chose 11 March 2020, as the date when the WHO declared COVID-19 a global pandemic [76].

We used the event study method to calculate abnormal returns during the pandemic, which is commonly used in similar studies analysing market reactions [77], showing the dynamics regarding a variable around the time of a specific event [78]. We calculated abnormal returns (ARs), for each company stock, $i$ on day $t$, using the daily-adjusted price. We used the Fama-French three-factor model, which controls for size and value [79], and is an improvement of the market model [80]. This model considers a variable for size (small to big market capitalization companies) and one for value (high to low book-to-market ratio) to mitigate the importance of the performance and risk of small companies compared to big ones.

Based on the related literature, and in order to improve the accuracy of our results and to ensure the results are not affected by stocks subject to long trading suspensions, we used the last 200 trading days from March 2019 to February 2020 as our estimation window [81]. For the Fama-French three-factor model, the daily yield for the Euro area 10-year bond yield was extracted from the European Central Bank database and the Fama and French three factors were taken from the website of Kenneth R. French.

The Fama-French three-factor model used in our research is defined as follows:

$$
R_{i, t}=\alpha_{i}+\beta_{i 1}\left(R_{m, t}-R_{f, t}\right)+\beta_{i 2} S M B_{t}+\beta_{i 3} H M L_{t}+\varepsilon_{i, t}
$$

where $R_{i, t}$ is the return of stock $i$ on day $t, R_{f, t}$ is the risk-free return on day $t$ using the Euro area 10-year bond yield, $R_{m, t}$ is the market return for the S\&P Europe 350 Index on day $t, \mathrm{SMB}_{\mathrm{t}}$ is the difference in returns between small and large capitalization firms on day $t$, $\mathrm{HML}_{\mathrm{t}}$ is the difference in returns between high and low book-to-market ratio stocks on day $t, \alpha_{\mathrm{i}}$ is the intercept of the relationship for stock $\mathrm{i}$, and $\varepsilon_{\mathrm{i}, t}$ is the error term for stock $i$ on day $t$.

With ordinary least square regressions, the coefficients $\hat{\alpha}_{\mathrm{i}}, \hat{\beta}_{\mathrm{i} 1}, \hat{\beta}_{\mathrm{i} 2}, \hat{\beta}_{\mathrm{i} 3}$ were computed using an estimation period, starting 200 trading days before the event and ending 11 trading days before it. Then, the abnormal return for stock $i$ on day $t$, and the cumulative abnormal return during the estimation window $t_{0}-t_{1}$ are estimated according to:

$$
\mathrm{AR}_{\mathrm{i}, \mathrm{t}}=\mathrm{R}_{\mathrm{i}, \mathrm{t}}-\left(\hat{\alpha}_{\mathrm{i}}+\hat{\beta}_{\mathrm{i} 1}\left(\mathrm{R}_{\mathrm{m}, \mathrm{t}}-\mathrm{R}_{\mathrm{f}, \mathrm{t}}\right)+\hat{\beta}_{\mathrm{i} 2} \mathrm{SMB}_{\mathrm{t}}+\hat{\beta}_{\mathrm{i} 3} \mathrm{HML}_{\mathrm{t}}\right)
$$

Next, the cumulative abnormal returns, the average abnormal returns for the sample of the stocks, and the cumulative average abnormal returns in the estimation window $t_{0}-t_{1}$ are estimated using Equations (3)-(5).

$$
\operatorname{CAR}_{i}\left(\mathrm{t}_{0}, \mathrm{t}_{1}\right)=\sum_{t=t_{0}}^{t_{1}} A R_{i, t}
$$




$$
\begin{gathered}
\mathrm{AAR}_{t}=\sum_{t=t_{0}}^{t_{1}} \frac{A R_{i, t}}{N} \\
\mathrm{CAAR}_{i}\left(\mathrm{t}_{0}, \mathrm{t}_{1}\right)=\sum_{t=t_{0}}^{t_{1}} A A R_{t}
\end{gathered}
$$

$\mathrm{N}$ is the number of companies in a sample (all of the electricity stocks, the renewable electricity stocks, and the traditional ones).

We used different intervals for the event window, as suggested by the literature regarding the effect of ESGs on company returns [73], before, during, and after the event: $(-5,0),(-3,0),(-2,2),(-1,1),(0,3)$ and $(0,5)$. We also computed CAARs for $(-10,0),(-5,0)$, $(0,0),(0,5)$, and $(0,10)$ for the WHO announcement, to show the evolution of abnormal returns during the pandemic with a longer time frame. To check the significance of the results, we used the Wilcoxon $\mathrm{z}$ test, since our data do not follow normal distribution [80].

As the objective of the paper was to analyse the influence of ESG factors on market returns during COVID-19, we used a cross-sectional analysis. As the dependent variable, we used CARs for the electricity companies from the event study and independent variables, which were also extracted from the Refinitiv EIKON Thomson Reuters database (ESG factors and firm variables). From the sample of 378 firms from Refinitiv EIKON, 280 were eliminated for having less than the 200 trading days needed for the event window, or for not having available stock information regarding the ESG scores and firm variables. The final sample consisted of 98 companies, with summary statistics presented in Table 1. However, not all of them have ESG scores; the sample of companies with these indicators consists of 37 firms.

\begin{tabular}{|c|c|c|c|c|c|c|}
\hline Variables & Unit & $\mathbf{N}$ & Mean & SD & Min & $\operatorname{Max}$ \\
\hline CAR $(-5,0)$ & $\%$ & 98 & -26.52 & 13.57 & -57.47 & 5.84 \\
\hline $\operatorname{CAR}(-3,0)$ & $\%$ & 98 & -21.81 & 12.02 & -50.32 & 6.04 \\
\hline $\operatorname{CAR}(-2,2)$ & $\%$ & 98 & -19.97 & 10.63 & -51.08 & 9.61 \\
\hline $\operatorname{CAR}(-1,1)$ & $\%$ & 98 & -12.64 & 7.69 & -33.35 & 9.49 \\
\hline $\operatorname{CAR}(0,3)$ & $\%$ & 98 & -14.83 & 8.94 & -34.20 & 9.59 \\
\hline CAR $(0,5)$ & $\%$ & 98 & -15.28 & 12.50 & -53.12 & 22.64 \\
\hline $\begin{array}{l}\text { Environmental } \\
\text { pillar score }\end{array}$ & number & 37 & 56.96 & 25.78 & 2.65 & 92.60 \\
\hline $\begin{array}{l}\text { Social pillar } \\
\text { score }\end{array}$ & number & 37 & 57.53 & 23.39 & 4.12 & 93.76 \\
\hline $\begin{array}{l}\text { Governance } \\
\text { pillar score }\end{array}$ & number & 40 & 51.61 & 20.05 & 15.93 & 89.52 \\
\hline $\begin{array}{l}\text { Total debt to } \\
\text { total equity }\end{array}$ & $\%$ & 92 & 173.69 & 271.57 & 0.00 & 1546.43 \\
\hline Beta & number & 95 & 0.65 & 0.41 & -0.54 & 2.17 \\
\hline Current ratio & number & 97 & 1.52 & 1.81 & 0.07 & 16.48 \\
\hline ln market cap & number & 96 & 20.18 & 2.60 & 15.12 & 25.15 \\
\hline ln total revenue & number & 96 & 20.41 & 2.03 & 14.23 & 25.19 \\
\hline Traditional & number & 98 & 0.81 & 0.40 & 0.00 & 1.00 \\
\hline
\end{tabular}

Table 1. Summary statistics.

After estimating the firm CARs for the different windows around the event (WHO announcement), we used the following OLS regression to check the different effects of the event on the two ways of producing energy and the influence of ESG scores:

$$
\begin{gathered}
\mathrm{CAR}_{\mathrm{i}(\mathrm{t} 1 \mathrm{t} 2)}=\mathrm{a}+\beta_{1} \text { Beta }+\beta_{2} \text { TotalDebttoTotalEquity }+\beta_{3} \text { CurrentRatio }+\beta_{4} \\
\text { lnmarketcap }+\beta_{5} \text { lntotalrevenue }+\beta_{6} \text { EnvironmentalPillarScore }+\beta_{7} \\
\text { SocialPillarScore }+\beta_{8} \text { GovernancePillarScore }+\beta_{9} \text { Traditional }+\varepsilon_{\mathrm{i}}
\end{gathered}
$$

where $\mathrm{CAR}_{\mathrm{i}(\mathrm{t} 1, \mathrm{t} 2)}$ is the cumulative abnormal return of the electricity company $\mathrm{i}$, EnvironmentalPillarScore, SocialPillarScore, and GovernancePillarScore, are the main ESG pillars, with values ranging from 0 to 100, for low (0) and high (100) ESG scores. The firm-specific 
control variables used in the paper are total debt to total equity to control for the level of leverage of the company, beta to control for the risk of the company, the current ratio for the level of liquidity, the natural logarithm of the market capitalization to control for size, and natural logarithm of total revenue to control for operational profit [16,73]. The ESG scores and the firm specific variables were extracted for 2019, with a lag of one, to address potential endogeneity [73]. We used an electricity sector dummy to control for the difference between traditional and renewable electricity companies, Traditional having a value of 1 if the company was a traditional electricity company and 0 if it was not (a renewable dummy was not used because of multi-collinearity). The intercept of the regression is "a", to measure excess returns after controlling for the independent variables.

\section{Results}

In this section, using the event study approach, we first estimated the CAARs for the COVID-19 pandemic announcement by the WHO, for the listed European electricity companies and for the two different ways of producing electricity. In that way, we can show whether there was a negative impact in this industry, and in the renewable and traditional sectors. Next, we used company CARs as dependent variables in multivariate regression models for different event windows, to corroborate the different impacts of COVID-19 in renewable and traditional sectors. After that, we checked whether the different ESG pillars influenced these CARs, and finally, checked the moderation influence, of the way of producing energy in relation to the ESG pillars.

\subsection{Event Study Analysis}

Table 2 confirms our H1a and H1b hypotheses. The electricity sector was negatively affected by the COVID-19 pandemic, as shown by the results in Table 2 and by the extensive literature on this subject $[47,80]$. There is also intra-sectoral differentiation between traditional electricity and renewable sources [33]. The CAARs were negative before and after the WHO announcement, with lower CAARs for the renewable sector (for example the CAAR for the event period $(-10,0)$ for renewable companies was $-32.04 \%$ and for traditional companies was $-29.77 \%$ ) compared with the ones for the traditional sector, as renewable electricity is considered riskier, with the negative effects impacting investor confidence for this type of energy. The difference between traditional electricity and renewable electricity is statistically significant ( $p$ value $<1 \%$ ), which underlines the results in Table 2.

\subsection{Cross-Sectional Analysis}

As stated above, there was a significant negative impact of the pandemic on electricity companies; the impact was more pronounced for renewable electricity companies than for traditional ones. Before analysing the significance of ESG scores during the pandemic on this specific sector, we ran a regression using only the firm specific variables and the dummy for traditional electricity companies, considering differences between countries, using the option cluster in Stata. Because of missing values, the total number of observations is 88. Table 3 shows the results of six regressions, the CARs for the companies used were estimated for six event windows (before, during, and after the WHO announcement of the pandemic). The $\mathrm{R}^{2}$ is quite low, showing that only around $10 \%$ of the change in abnormal returns is explained by the inclusion of the independent variables. The systemic risk beta, current ratio, and market capitalization positively influence the abnormal returns during the pandemic, with statistically significant coefficients, in line with the literature [16,73], and total revenue negatively affect the return, as bad events have a potential to impact future sales. The traditional dummy coefficients show that, before, during, and after the declaration of the pandemic, traditional electricity companies were less affected by COVID19 in comparison to renewable companies, which underlines the impact demonstrated in Table 2. This result corroborates H1b. Moreover, the sector dummy had the biggest impact in relation to the other control variables on abnormal returns during the pandemic. 
Table 2. The cumulative average abnormal returns for the electricity sector for the WHO announcement for the 98 companies.

\begin{tabular}{cccc}
\hline & Electricity Sector & Traditional Sector & Renewable Sector \\
\hline Event window & CAAR & CAAR & CAAR \\
$(-10,0)$ & $-30.43 \%^{* * *}$ & $-29.77 \% * * *$ & $-32.04 \% * * *$ \\
$(-5,0)$ & $-28.8 \%^{* * *}$ & $-27.25 \% * * *$ & $-34.08 \% * * *$ \\
$(0,0)$ & $-11.91 \%^{* * *}$ & $-11.15 \%^{* * *}$ & $-15.11 \% * * *$ \\
$(0,5)$ & $-14.20 \% * * *$ & $-13.39 \%^{* * *}$ & $-17.73 \% * * *$ \\
$(0,10)$ & $-5.09 \%^{* * *}$ & $-5.03 \% * * *$ & $-5.46 \% * * *$ \\
\hline
\end{tabular}

Notes: ${ }^{* * *}$ denotes statistical significance at $1 \%$ level using the Wilcoxon $\mathrm{z}$ test. Source: own calculations.

Table 3. CAR regression results using the firm specific variables and sector dummy.

\begin{tabular}{ccccccc}
\hline & CAR & CAR & CAR & CAR & CAR (0,3) & CAR (0,5) \\
& $(\mathbf{- 5 , 0 )}$ & $\mathbf{( - 3 , 0 )}$ & $\mathbf{( - 2 , 2 )}$ & $\mathbf{( - 1 , 1 )}$ & & \\
\hline Beta & 0.0220 & 0.0315 & $0.0686^{*}$ & $0.0595^{*}$ & $0.0458^{* * *}$ & 0.0346 \\
& $(0.0347)$ & $(0.0282)$ & $(0.0235)$ & $(0.0200)$ & $(0.0244)$ & $(0.0360)$ \\
Total debt to & -0.0015 & -0.0005 & -0.0006 & -0.0047 & 0.0008 & 0.0057 \\
total equity & $(0.0053)$ & $(0.0056)$ & $(0.0029)$ & $(0.0030)$ & $(0.0031)$ & $(0.0047)$ \\
& 0.0015 & 0.0034 & $0.0072 * * *$ & 0.0005 & $0.0087 * *$ & $0.0111^{* *}$ \\
Current ratio & $(0.0021)$ & $(0.0020)$ & $(0.0035)$ & $(0.0026)$ & $(0.0037)$ & $(0.0040)$ \\
& $0.0261 * *$ & $0.0187^{* * *}$ & 0.0078 & 0.0114 & 0.0019 & 0.0091 \\
lnmarketcap & $(0.0106)$ & $(0.0089)$ & $(0.0084)$ & $(0.0067)$ & $(0.0075)$ & $(0.0072)$ \\
& $-0.0418^{*}$ & $-0.0306^{* *}$ & -0.0195 & -0.0184 & -0.0068 & -0.0071 \\
Intotalrevenue & $(0.0137)$ & $(0.0116)$ & $(0.0111)$ & $(0.0104)$ & $(0.0100)$ & $(0.0083)$ \\
Traditional & $0.1140^{*}$ & $0.1035^{*}$ & 0.0585 & $0.0610 * *$ & 0.0252 & $0.0522 * * *$ \\
Constant & $(0.0393)$ & $(0.0346)$ & $(0.0345)$ & $(0.0270)$ & $(0.0265)$ & $(0.0280)$ \\
& -0.0403 & -0.0728 & -0.0542 & -0.0573 & -0.1154 & -0.2873 \\
Observations & $(0.1117)$ & $(0.1079)$ & $(0.0836)$ & $(0.0786)$ & $(0.1219)$ & $(0.1388)$ \\
$R^{2}$ & 88 & 88 & 88 & 88 & 88 & 88 \\
& 0.118 & 0.109 & 0.161 & 0.238 & 0.089 & 0.067
\end{tabular}

Standard errors in parentheses. ${ }^{* * *} p<0.01,{ }^{* *} p<0.05,{ }^{*} p<0.10$, denote significance at the $1 \%, 5 \%$, and $10 \%$ levels, respectively. Source: own calculations.

Next, we computed the regression for the CARs for electricity firms, including the environmental pillar, social pillar, and governance pillar (ESG) scores, the firm specific variables and the sector dummy, with cluster countries. The Thomson Reuters database contains data related to the three ESG pillars, only for 37 companies out of the total population; nevertheless, the $\mathrm{R}^{2}$ in Table 4 has significantly increased, showing that $21.5 \%$ to $56.5 \%$ of the change in abnormal returns is explained by the inclusion of the independent variables. These results reflect that, in general, the ESGs were not statistically significant during the pandemic, as shown by a part of the literature that stated that ESG disclosure was not relevant during the pandemic $[14,82]$. The traditional dummy was significant only during the event window $(-1,1)$ and $(0,5)$, close to the event period and after the event. These results reject our hypotheses $\mathrm{H} 2 \mathrm{a}, \mathrm{H} 2 \mathrm{~b}$, and $\mathrm{H} 2 \mathrm{c}$, and are in line with the literature suggesting the non-influence of ESG scores [22], but also with the empirical evidence in favour of ESG score influence being sector-specific $[21,27,74]$. To further analyse the effects of ESG disclosure on abnormal returns during the pandemic under the influence of the sectorial way of producing electricity, we used a regression with interaction terms between the sector dummy (traditional) and the three ESG pillars. 
Table 4. CAR regression results using ESG scores, firm specific variables, and sector dummy.

\begin{tabular}{|c|c|c|c|c|c|c|}
\hline & $\begin{array}{c}\text { CAR } \\
(-5,0)\end{array}$ & $\begin{array}{c}\text { CAR } \\
(-3,0)\end{array}$ & $\begin{array}{c}\text { CAR } \\
(-2,2)\end{array}$ & $\begin{array}{l}\text { CAR } \\
(-1,1)\end{array}$ & $\operatorname{CAR}(0,3)$ & $\operatorname{CAR}(0,5)$ \\
\hline Beta & $\begin{array}{c}-0.1554^{* *} \\
(0.0593)\end{array}$ & $\begin{array}{c}-0.1133^{* * *} \\
(0.0538)\end{array}$ & $\begin{array}{l}-0.0705 \\
(0.0431)\end{array}$ & $\begin{array}{c}-0.1108 * \\
(0.0323)\end{array}$ & $\begin{array}{c}0.0087 \\
(0.0766)\end{array}$ & $\begin{array}{c}0.0333 \\
(0.1254)\end{array}$ \\
\hline Total Debt to & 0.0115 & 0.0116 & 0.0013 & 0.0118 * & 0.0049 & -0.0032 \\
\hline & $(0.0107)$ & $(0.0090)$ & $(0.0061)$ & $(0.0037)$ & $(0.0084)$ & $(0.0126)$ \\
\hline Current ratio & $\begin{array}{c}0.0046 \\
(0.0207)\end{array}$ & $\begin{array}{c}0.0042 \\
(0.0175)\end{array}$ & $\begin{array}{c}0.0136 \\
(0.0129)\end{array}$ & $\begin{array}{l}0.0147^{*} \\
(0.0029)\end{array}$ & $\begin{array}{l}-0.0055 \\
(0.0157)\end{array}$ & $\begin{array}{l}-0.0350 \\
(0.0201)\end{array}$ \\
\hline lnmarketcap & $\begin{array}{c}-0.0573^{*} \\
(0.0161)\end{array}$ & $\begin{array}{c}-0.0417^{* *} \\
(0.0141)\end{array}$ & $\begin{array}{l}-0.0165 \\
(0.0156)\end{array}$ & $\begin{array}{l}-0.0088 \\
(0.0068)\end{array}$ & $\begin{array}{l}-0.0081 \\
(0.0167)\end{array}$ & $\begin{array}{l}-0.0100 \\
(0.0180)\end{array}$ \\
\hline lntotalrevenue & $\begin{array}{l}0.0314^{* *} \\
(0.0120)\end{array}$ & $\begin{array}{l}0.0235^{* * *} \\
(0.0091)\end{array}$ & $\begin{array}{c}0.0018 \\
(0.0131)\end{array}$ & $\begin{array}{c}0.0058 \\
(0.0088)\end{array}$ & $\begin{array}{l}-0.0015 \\
(0.0177)\end{array}$ & $\begin{array}{l}-0.0177 \\
(0.0304)\end{array}$ \\
\hline $\begin{array}{l}\text { Environmental } \\
\text { Pillar Score }\end{array}$ & 0.0008 & 0.0005 & 0.0003 & $0.0010^{* * *}$ & -0.0004 & -0.0022 \\
\hline & $(0.0010)$ & $(0.0010)$ & $(0.0009)$ & $(0.0005)$ & $(0.0010)$ & $(0.0015)$ \\
\hline $\begin{array}{c}\text { Social Pillar } \\
\text { Score }\end{array}$ & -0.0020 & -0.0016 & -0.0004 & -0.0004 & 0.0002 & 0.0004 \\
\hline & $(0.0016)$ & $(0.0015)$ & $(0.0011)$ & $(0.0005)$ & $(0.0012)$ & $(0.0014)$ \\
\hline $\begin{array}{l}\text { Governance } \\
\text { Pillar Score }\end{array}$ & -0.0003 & -0.0004 & 0.0002 & -0.0004 & 0.0014 & 0.0021 \\
\hline & (0.0009) & $(0.0007)$ & $(0.0008)$ & $(0.0004)$ & $(0.0011)$ & $(0.0017)$ \\
\hline Traditional & $\begin{array}{c}0.0872 \\
(0.0650)\end{array}$ & $\begin{array}{c}0.0908 \\
(0.0559)\end{array}$ & $\begin{array}{c}0.0888 \\
(0.0508)\end{array}$ & $\begin{array}{c}0.0599 * * * \\
(0.0317)\end{array}$ & $\begin{array}{c}0.0601 \\
(0.0717)\end{array}$ & $\begin{array}{c}0.1748^{* * *} \\
(0.0903)\end{array}$ \\
\hline Constant & $\begin{array}{c}0.3807 \\
(0.3197)\end{array}$ & $\begin{array}{c}0.2188 \\
(0.2575)\end{array}$ & $\begin{array}{c}0.0606 \\
(0.2747)\end{array}$ & $\begin{array}{l}-0.0895 \\
(0.1743)\end{array}$ & $\begin{array}{l}-0.0343 \\
(0.3535)\end{array}$ & $\begin{array}{c}0.3609 \\
(0.5920)\end{array}$ \\
\hline Observations & 37 & 37 & 37 & 37 & 37 & 37 \\
\hline$R^{2}$ & 0.474 & 0.462 & 0.314 & 0.567 & 0.215 & 0.360 \\
\hline
\end{tabular}

Standard errors in parentheses. ${ }^{* *} p<0.01,{ }^{* *} p<0.05,{ }^{*} p<0.10$, denote significance at the $1 \%, 5 \%$, and $10 \%$ levels, respectively. Source: own calculations.

\subsection{Moderation Effects of EGS Factors}

To analyse the interaction between the sector dummy variable and the three ESG scores-to shed light on the idea that ESG factors and sectors are context contingent, we use the following regression:

$$
\begin{gathered}
\mathrm{CAR}_{\mathrm{i}(\mathrm{t} 1, \mathrm{t} 2)}=\mathrm{a}+\beta_{1} \text { Beta }+\beta_{2} \text { TotalDebttoTotalEquity }+\beta_{3} \text { CurrentRatio }+\beta_{4} \\
\text { lnmarketcap }+\beta_{5} \text { lntotalrevenue }+\beta_{6} \text { Traditional }+\beta_{7} \\
\text { EnvironmentalPillarScore }+\beta_{8} \text { Traditional } * \text { EnvironmentalPillarScore }+\beta_{9} \\
\text { SocialPillarScore }+\beta_{10} \text { Traditional } * \text { SocialPillarScore }+\beta_{11} \\
\text { GovernancePillarScore }+\beta_{12} \text { Traditional } * \text { GovernancePillarScore }+\varepsilon_{\mathrm{i}}
\end{gathered}
$$

Table 5 presents the results of the regression mentioned above. The $\mathrm{R}^{2}$ increased significantly, with a minimum of $38.9 \%$ and a maximum of $72.8 \%$, indicating the sectoral dependency on the ESG influence represented by the moderations, which increases the explanatory power of the model. 
Table 5. CAR regression results using ESG scores, firm specific variables, and sector dummy, and the interaction between the sector dummy and the ESG scores.

\begin{tabular}{|c|c|c|c|c|c|c|}
\hline & $\operatorname{CAR}(-5,0)$ & $\operatorname{CAR}(-3,0)$ & $\operatorname{CAR}(-2,2)$ & $\operatorname{CAR}(-1,1)$ & CAR $(0,3)$ & CAR $(0,5)$ \\
\hline Beta & $\begin{array}{l}-0.1849 * \\
(0.0492)\end{array}$ & $\begin{array}{l}-0.1455^{*} \\
(0.0477)\end{array}$ & $\begin{array}{l}-0.0976^{* *} \\
(0.0415)\end{array}$ & $\begin{array}{l}-0.1213 * \\
(0.0346)\end{array}$ & $\begin{array}{l}-0.0133 \\
(0.0772)\end{array}$ & $\begin{array}{c}0.0101 \\
(0.1495)\end{array}$ \\
\hline Total Debt to Total Equity & $\begin{array}{c}0.0089 \\
(0.0094)\end{array}$ & $\begin{array}{c}0.0104 \\
(0.0084)\end{array}$ & $\begin{array}{l}-0.0026 \\
(0.0034)\end{array}$ & $\begin{array}{l}0.0110 * \\
(0.0032)\end{array}$ & $\begin{array}{c}0.0032 \\
(0.0075)\end{array}$ & $\begin{array}{l}-0.0046 \\
(0.0177)\end{array}$ \\
\hline Current ratio & $\begin{array}{c}0.0067 \\
(0.0194)\end{array}$ & $\begin{array}{c}0.0046 \\
(0.0156)\end{array}$ & $\begin{array}{c}0.0161 \\
(0.0102)\end{array}$ & $\begin{array}{l}0.0157^{*} \\
(0.0035)\end{array}$ & $\begin{array}{l}-0.0044 \\
(0.0136)\end{array}$ & $\begin{array}{l}-0.0346^{* * *} \\
(0.0158)\end{array}$ \\
\hline lnmarketcap & $\begin{array}{l}-0.0533^{* *} \\
(0.0186)\end{array}$ & $\begin{array}{l}-0.0406^{*} \\
(0.0134)\end{array}$ & $\begin{array}{l}-0.0208 \\
(0.0188)\end{array}$ & $\begin{array}{l}-0.0040 \\
(0.0099)\end{array}$ & $\begin{array}{l}-0.0077 \\
(0.0192)\end{array}$ & $\begin{array}{l}-0.0133 \\
(0.0240)\end{array}$ \\
\hline lntotalrevenue & $\begin{array}{c}0.0263 \\
(0.0150)\end{array}$ & $\begin{array}{l}0.0209^{* * * *} \\
(0.0110)\end{array}$ & $\begin{array}{c}0.0021 \\
(0.0155)\end{array}$ & $\begin{array}{c}0.0017 \\
(0.0102)\end{array}$ & $\begin{array}{l}-0.0033 \\
(0.0172)\end{array}$ & $\begin{array}{l}-0.0169 \\
(0.0323)\end{array}$ \\
\hline Traditional & $\begin{array}{l}0.3084^{*} \\
(0.0577)\end{array}$ & $\begin{array}{l}0.2863 * \\
(0.0522)\end{array}$ & $\begin{array}{l}0.1606^{* * *} \\
(0.0767)\end{array}$ & $\begin{array}{l}0.1936^{* *} \\
(0.0737)\end{array}$ & $\begin{array}{l}0.1841 * \\
(0.0581)\end{array}$ & $\begin{array}{l}0.2488^{* * * *} \\
(0.1213)\end{array}$ \\
\hline Environmental Pillar Score & $\begin{array}{l}0.0060 * \\
(0.0007)\end{array}$ & $\begin{array}{l}0.0047 * \\
(0.0006)\end{array}$ & $\begin{array}{l}0.0041 * \\
(0.0008)\end{array}$ & $\begin{array}{l}0.0035^{*} \\
(0.0011)\end{array}$ & $\begin{array}{c}0.0028 \\
(0.0017)\end{array}$ & $\begin{array}{c}0.0002 \\
(0.0023)\end{array}$ \\
\hline $\begin{array}{l}\text { Traditional x } \\
\text { Environmental Pillar Score }\end{array}$ & $-0.0060 *$ & $-0.0047^{*}$ & $-0.0044^{*}$ & $-0.0029^{* *}$ & $-0.0037^{* * *}$ & -0.0027 \\
\hline Social Pillar Score & $\begin{array}{c}(0.0016) \\
0.0008 \\
(0.0016)\end{array}$ & $\begin{array}{c}(0.0014) \\
0.0018 \\
(0.0012)\end{array}$ & $\begin{array}{c}(0.0013) \\
0.0024^{* * *} \\
(0.0011)\end{array}$ & $\begin{array}{c}(0.0012) \\
0.0004 \\
(0.0014)\end{array}$ & $\begin{array}{c}(0.0018) \\
0.0025^{* * *} \\
(0.0013)\end{array}$ & $\begin{array}{c}(0.0031) \\
0.0029 \\
(0.0031)\end{array}$ \\
\hline $\begin{array}{l}\text { Traditional x Social } \\
\text { Pillar Score }\end{array}$ & -0.0029 & -0.0037 & -0.0026 & -0.0009 & -0.0024 & -0.0027 \\
\hline & $(0.0029)$ & $(0.0024)$ & $(0.0018)$ & $(0.0016)$ & $(0.0015)$ & $(0.0042)$ \\
\hline Governance Pillar Score & $\begin{array}{l}-0.0051^{* *} \\
(0.0020)\end{array}$ & $\begin{array}{c}-0.0052 * \\
(0.0015)\end{array}$ & $\begin{array}{l}-0.0051^{*} \\
(0.0010)\end{array}$ & $\begin{array}{l}-0.0019 \\
(0.0013)\end{array}$ & $\begin{array}{l}-0.0022 \\
(0.0013)\end{array}$ & $\begin{array}{l}-0.0016 \\
(0.0026)\end{array}$ \\
\hline $\begin{array}{c}\text { Traditional x Governance } \\
\text { Pillar Score }\end{array}$ & $0.0053^{* *}$ & $0.0052 *$ & $0.0061 *$ & 0.0016 & $0.0040^{* *}$ & 0.0043 \\
\hline & $(0.0019)$ & $(0.0015)$ & $(0.0016)$ & $(0.0014)$ & $(0.0018)$ & $(0.0029)$ \\
\hline Constant & $\begin{array}{c}0.2351 \\
(0.3088)\end{array}$ & $\begin{array}{c}0.1115 \\
(0.2347)\end{array}$ & $\begin{array}{c}0.0799 \\
(0.2700)\end{array}$ & $\begin{array}{l}-0.2053 \\
(0.1801)\end{array}$ & $\begin{array}{l}-0.0959 \\
(0.4051)\end{array}$ & $\begin{array}{c}0.3613 \\
(0.6975)\end{array}$ \\
\hline Observations & 37 & 37 & 37 & 37 & 37 & 37 \\
\hline$R^{2}$ & 0.667 & 0.698 & 0.603 & 0.728 & 0.389 & 0.403 \\
\hline
\end{tabular}

Standard errors in parentheses. ${ }^{* *} p<0.01,{ }^{* *} p<0.05, * p<0.10$, denote significance at the $1 \%, 5 \%$, and $10 \%$ levels, respectively. Source: own calculations.

The interpretation of the results pertaining to the ESG scores and their interaction with the dummy variables is that traditional electricity companies were hit less by the pandemic in comparison to the renewable ones, corroborating, again, H1b, as showed in Tables 2 and 3.

The results shown in Table 5 confirm H3a, since the effect of environmental pillar scores is positive and significant (for instance, the coefficient -0.00602 for CAR $(-5,0)$ for renewable companies for most of the CAR windows. However, our H3b hypothesis cannot be confirmed, as the coefficients in all interactions are not significant (for instance, the coefficient -0.00293 for CAR $(-5,0)$. Finally, our H3c hypothesis is rejected, since the coefficients in the moderation are significant, but they show that the effect of governance pillar scores were negative for renewable companies (for instance, the coefficient 0.00528 for CAR $(-5,0)$.

Next, to gain a deeper understanding of the interactions [83-85], we plotted the moderation effect of environmental and governance pillar scores to the traditional variable. Following the literature, we adopted the approach suggested by Dawson and Richter [86], and we graphed both interactions [87]. Figure 1 shows that renewable companies improve their CARs when presenting higher environmental scores, in favour of H3a. However, Figure 2 shows the opposite effect, since renewable companies with higher governance scores present lower CARs, against H3c. 


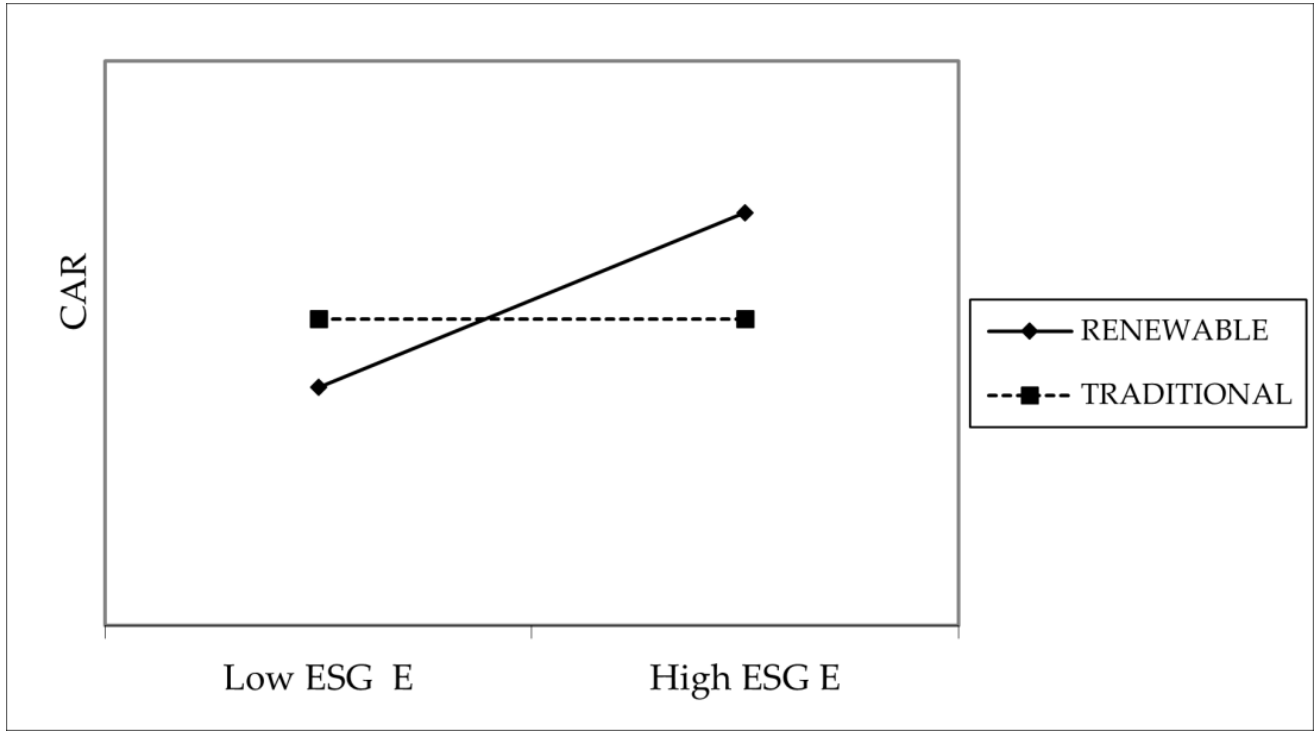

Figure 1. Moderation effect of environmental pillar score and traditional variable.

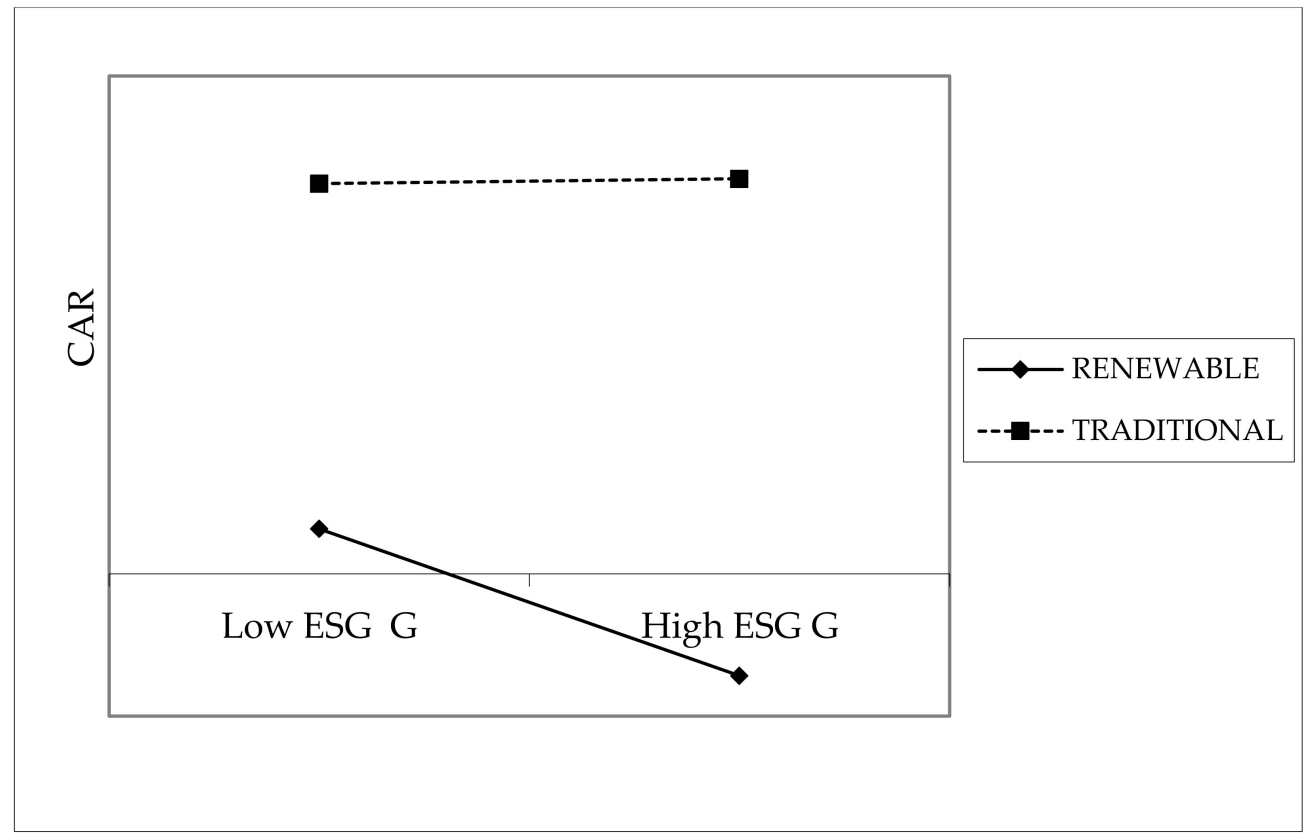

Figure 2. Moderation effect of governance pillar score and traditional variable.

Finally, using the event study to calculated firm CARs, we split the company bases on average values of the ESG pillar scores, and then tested the difference between the low ESG pillar and high ESG pillar. The results are in line with what is presented in Table 5, and the related figures above. Table 6 presents the results related to these differences. For renewable companies, firms with high environmental and social scores show higher CARs, decreasing the effect of the pandemic. For traditional companies the effect was the opposite. Regarding the governance pillar, companies with high governance scores present lower CARs, and with low governance scores present higher CARs. 
Table 6. The difference in CARs between low ESG pillar scores and high ESG pillar scores.

\begin{tabular}{|c|c|c|c|c|c|c|}
\hline & $\begin{array}{c}\text { Low E } \\
\text { for } \\
\text { Traditional }\end{array}$ & $\begin{array}{c}\text { Low E } \\
\text { for } \\
\text { Renewable }\end{array}$ & $\begin{array}{c}\text { Low } S \\
\text { for } \\
\text { Traditional }\end{array}$ & $\begin{array}{c}\text { Low } S \\
\text { for } \\
\text { Renewable }\end{array}$ & $\begin{array}{c}\text { Low G } \\
\text { for } \\
\text { Traditional }\end{array}$ & $\begin{array}{c}\text { Low G } \\
\text { for } \\
\text { Renewable }\end{array}$ \\
\hline High E for Traditional & $0.0606^{* * *}$ & & & & & \\
\hline High E for Renewable & & $-0.1083^{* * *}$ & & & & \\
\hline High E for Traditional & & & $0.0557 * * *$ & & & \\
\hline High S for Renewable & & & & $-0.0223 * *$ & & \\
\hline High $G$ for Traditional & & & & & -0.0008 & \\
\hline High G for Renewable & & & & & & $0.0197^{* * *}$ \\
\hline
\end{tabular}

Standard errors in parentheses. ${ }^{* *} p<0.01,{ }^{* *} p<0.05$, denote significance at the $5 \%$, and $1 \%$ levels, respectively. E represents the environmental pillar, $\mathrm{S}$ the social pillar, and $\mathrm{G}$ the governance pillar. Source: own calculations.

\section{Discussion and Conclusions}

This study used two different methodologies, event study and multivariate regressions, to check the influence of the COVID-19 pandemic and ESG scores on listed European electricity companies, distinguishing between renewable and traditional energy.

The electricity sector suffered a large negative influence, since the COVID-19 pandemic had a severe general impact on the mobility of the population, traffic of goods, and industrial activity. In this study, we first provided evidence of the decline in returns for electricity companies in Europe, distinguishing between traditional and renewable production. Using the event study approach, we showed that the pandemic had a significant negative impact on the electricity sector, with renewable companies suffering a sharper decline than traditional electricity companies. COVID-19 led the economy to a halt, resulting in, among other factors, a substantial reduction in electricity consumption, financial markets profitability, and volatility [24]. The larger negative impact on renewable energy can be explained by its riskier investment profile due to its weather dependence and the uncertainty of the supply reliability and financial returns $[63,64]$. The renewable energy sector also demands a high capital investment, which involves difficulties in breakingeven [66]. A better understanding can help decision-makers in future crises, and reveal potential opportunities [58]. Moreover, this pandemic may be the stimulus for change in the European energy transition, helping policymakers, researchers, and investors ensure this transition will be successful [63].

An important contribution of our research was in analysing the influence of environmental, social, and governance indicators (E, S, G) on stock returns during the COVID-19 pandemic, focusing on the WHO announcement on 11 March, 2021, as the event date. In line with recent literature $[22,68]$, stating the necessity of making more detailed research to understand what pillars really affect company performances, our results show the different influences of them. When the environmental, social and governance pillar scores stood alone, they were not statistically significant during the pandemic, which is in line with the current literature stating that ESG factors are not relevant $[22,24,25]$ during the pandemic $[14,75]$.

However, along with the idea that ESG factors are sector- and context-specific $[19,27]$, when the sector dummy-traditional company interacted with the ESG scores, we find that, for renewable electricity companies, the returns were positively influenced by the environmental and social pillars, even though the environmental pillar was only significant, as these companies are more involved in environmental and social disclosure procedures compared to traditional electricity companies. Companies with high environmental and social disclosure scores had high stock returns during the pandemic propagation period [72]. Efforts related to environmental activities for traditional electricity companies did not have a direct impact on financial performance, because it is hard to achieve tangible outcomes with only a firm's effort [88]. The governance pillar positively affected traditional electricity and negatively affected renewable companies. The governance score does not always have a clear effect on stock returns, especially during COVID-19. Garel and Petit- 
Romec [89], even though they did not find strong evidence that corporate governance influenced stock returns during the COVID-19 crisis, due to the uncertainty created by the pandemic, they showed that investors may prize corporate control flexibility, penalizing corporate governance mechanisms that reduce that flexibility. As governance scores capture a company's commitment towards mechanisms that help in the demanded flexibility, such as takeovers, these mechanisms may be negatively rewarded by investors that demand flexibility in renewable companies due to their greater exposure to the negative effects of COVID-19, and to their riskier investment profiles. This is in line with the governance mechanisms failing to mitigate, at the firm level, the discrepancies between the market and the company management. We should note that Yen and André [90] found that active investors tend to have a less stable ownership structure.

The implications of our findings are relevant for researchers, public institutions, investors, and policymakers. Our results show the importance of analysing, in a deeper way, the different influences of ESG pillars, since they may affect differently, depending on the context and sector. In that way, it could help to shed light on the (sometimes-puzzling) findings in the literature. It also proves the heterogeneous risk profile and market response of the energy sector, which could help in the design of specific policies that mitigate and adapt to the different risk profiles and circumstances. We provide a better understanding of the investment portfolio sectorial analysis.

Our study has some limitations. We should note that there are other factors that might impact market returns beyond the identified events, so an extensive investigation has to be carried out on the other specific links between ESG scores and market returns. Additionally, we are aware of the small size of our sample of companies, considering the large population of electricity companies in Europe.

In future lines of research, and to further mitigate the reduced size of our sample, the sample should be extended to other regions, considering specific market characteristics. Moreover, it would be interesting to extend this analysis to different continents.

Author Contributions: Conceptualization, F.T.B. and J.A.C.-A.; methodology, F.T.B. and J.A.C.-A.; software, F.T.B.; validation, F.T.B. and J.A.C.-A.; formal analysis, F.T.B. and J.A.C.-A.; investigation, F.T.B. and J.A.C.-A.; resources, F.T.B., J.A.C.-A., I.T. and L.A.S.-A.; data curation, F.T.B. and J.A.C.A.; writing-original draft preparation, F.T.B. and J.A.C.-A.; writing-review and editing, F.T.B., J.A.C.-A., I.T. and L.A.S.-A.; visualization, F.T.B., J.A.C.-A. and I.T.; supervision, F.T.B., J.A.C.-A. and I.T.; project administration, F.T.B., J.A.C.-A., I.T. and L.A.S.-A.; funding acquisition, I.T. All authors have read and agreed to the published version of the manuscript.

Funding: This research received no external funding.

Institutional Review Board Statement: Not applicable.

Informed Consent Statement: Not applicable.

Data Availability Statement: The data presented in this study are available upon request.

Conflicts of Interest: The authors declare no conflict of interest.

\section{References}

1. Del Giudice, A.; Paltrinieri, A. The impact of the Arab Spring and the Ebola outbreak on African equity mutual fund investor decisions. Res. Int. Bus. Financ. 2017, 41, 600-612. [CrossRef]

2. Siddique, A.; Shahzad, A.; Lawler, J.; Mahmoud, K.A.; Lee, D.S.; Ali, N.; Bilal, M.; Rasool, K. Unprecedented environmental and energy impacts and challenges of COVID-19 pandemic. Environ. Res. 2021, 193, 110443. [CrossRef] [PubMed]

3. Schell, D.; Wang, M.; Huynh, T.L.D. This time is indeed different: A study on global market reactions to public health crisis. J. Behav. Exp. Financ. 2020, 27, 100349. [CrossRef] [PubMed]

4. Albulescu, C.T. COVID-19 and the United States financial markets' volatility. Financ. Res. Lett. 2021, 38, 101699. [CrossRef] [PubMed]

5. He, P.; Sun, Y.; Zhang, Y.; Li, T. COVID-19's Impact on Stock Prices Across Different Sectors-An Event Study Based on the Chinese Stock Market. Emerg. Mark. Financ. Trade 2020, 56, 2198-2212. [CrossRef]

6. Ambros, M.; Frenkel, M.; Huynh, T.L.D.; Kilinc, M. COVID-19 pandemic news and stock market reaction during the onset of the crisis: Evidence from high-frequency data. Appl. Econ. Lett. 2020, 28, 1686-1689. [CrossRef] 
7. Niţoi, M.; Pochea, M.M. Time-varying dependence in European equity markets: A contagion and investor sentiment driven analysis. Econ. Model. 2020, 86, 133-147. [CrossRef]

8. Rizwan, M.S.; Ahmad, G.; Ashraf, D. Systemic risk: The impact of COVID-19. Financ. Res. Lett. 2020, 36, 101682. [CrossRef] [PubMed]

9. Saadat, S.; Rawtani, D.; Hussain, C.M. Environmental perspective of COVID-19. Sci. Total Environ. 2020, 728, 138870. [CrossRef] [PubMed]

10. Campra, M.; Esposito, P.; Brescia, V. State of the Art of COVID-19 and Business, Management, and Accounting Sector. A Bibliometrix Analysis. Int. J. Bus. Manag. 2020, 16, 35-52. [CrossRef]

11. Secinaro, S.; Calandra, D.; Biancone, P.P. Reflection on Coronavirus Accounting Impact on Small and Medium Sized Enterprises (SMEs) in Europe. Int. J. Bus. Manag. 2020, 15, 48. [CrossRef]

12. Sheehy, B. Defining CSR: Problems and Solutions. J. Bus. Ethic 2015, 131, 625-648. [CrossRef]

13. Broadstock, D.C.; Chan, K.; Cheng, L.T.; Wang, X. The role of ESG performance during times of financial crisis: Evidence from COVID-19 in China. Financ. Res. Lett. 2021, 38, 101716. [CrossRef] [PubMed]

14. Demers, E.; Hendrikse, J.; Joos, P.; Lev, B. ESG did not immunize stocks during the COVID-19 crisis, but investments in intangible assets did. J. Bus. Financ. Account. 2021, 48, 433-462. [CrossRef]

15. Ionescu, G.H.; Firoiu, D.; Pirvu, R.; Vilag, R.D. The impact of esg factors on market value of companies from travel and tourism industry. Technol. Econ. Dev. Econ. 2019, 25, 820-849. [CrossRef]

16. Clark, J.; Mauck, N.; Pruitt, S.W. The financial impact of COVID-19: Evidence from an event study of global hospitality firms. Res. Int. Bus. Financ. 2021, 58, 101452. [CrossRef]

17. Amer, E. The Penalization of Non-Communicating UN Global Compact's Companies by Investors and Its Implications for This Initiative's Effectiveness. Bus. Soc. 2015, 57, 255-291. [CrossRef]

18. Willis, C.A.A. The Role of the Global Reporting Initiative's Sustainability Reporting Guidelines in the Social Screening of Investments. J. Bus. Ethic 2003, 43, 233-237. [CrossRef]

19. Lee, Y.-J.; Zhang, X.T. AI-Generated Corporate Environmental Data: An Event Study with Predictive Power. Int. Financ. Rev. 2019, 20, 65-83. [CrossRef]

20. Cheng, B.; Ioannou, I.; Serafeim, G. Corporate social responsibility and access to finance. Strateg. Manag. J. 2014, 35, 1-23. [CrossRef]

21. Khan, M.; Serafeim, G.; Yoon, A. Corporate Sustainability: First Evidence on Materiality. Account. Rev. 2016, 91, 1697-1724. [CrossRef]

22. Capelle-Blancard, G.; Petit, A. The Weighting of CSR Dimensions: One Size Does Not Fit All. Bus. Soc. 2015, 56, 919-943. [CrossRef]

23. Orlitzky, M. Corporate Social Responsibility, Noise, and Stock Market Volatility. Acad. Manag. Perspect. 2013, 27, 238-254. [CrossRef]

24. Sabbaghi, O.; Xu, M. ROE and Corporate Social Responsibility: Is There a Return On Ethics? J. Account. Financ. $2013,13,82-95$.

25. Mitsuyama, N.; Shimizutani, S. Stock market reaction to ESG-oriented management: An event study analysis on a disclosing policy in Japan. Econ. Bull. 2015, 35, 1098-1108.

26. Sassen, R.; Hinze, A.-K.; Hardeck, I. Impact of ESG factors on firm risk in Europe. Z. Betr. 2016, 86, 867-904. [CrossRef]

27. Amel-Zadeh, A.; Serafeim, G. Why and How Investors Use ESG Information: Evidence from a Global Survey. Financ. Anal. J. 2018, 74, 87-103. [CrossRef]

28. Krüger, P. Corporate goodness and shareholder wealth. J. Financ. Econ. 2015, 115, 304-329. [CrossRef]

29. Ferriani, F.; Natoli, F. ESG risks in times of Covid-19. Appl. Econ. Lett. 2020, 28, 1-5. [CrossRef]

30. Pavlova, I.; de Boyrie, M.E. ESG ETFs and the COVID-19 stock market crash of 2020: Did clean funds fare better? Financ. Res. Lett. 2021, 102051. [CrossRef]

31. Mukanjari, S.; Sterner, T. Charting a "Green Path" for Recovery from COVID-19. Environ. Resour. Econ. 2020, 76, 825-853. [CrossRef] [PubMed]

32. Peña-Ramos, J.A.; Bagus, P.; Amirov-Belova, D. The North Caucasus Region as a Blind Spot in the "European Green Deal": Energy Supply Security and Energy Superpower Russia. Energies 2020, 14, 17. [CrossRef]

33. Zhang, D.; Cao, H.; Dickinson, D.G.; Kutan, A.M. Free cash flows and overinvestment: Further evidence from Chinese energy firms. Energy Econ. 2016, 58, 116-124. [CrossRef]

34. Gugler, K.; Rammerstorfer, M.; Schmitt, S. Ownership unbundling and investment in electricity markets-A cross country study. Energy Econ. 2013, 40, 702-713. [CrossRef]

35. Zhang, D.; Cao, H.; Zou, P. Exuberance in China's renewable energy investment: Rationality, capital structure and implications with firm level evidence. Energy Policy 2016, 95, 468-478. [CrossRef]

36. Huynh, T.L.D.; Foglia, M.; Doukas, J.A. COVID-19 and Tail-event Driven Network Risk in the Eurozone. Financ. Res. Lett. 2021, 44, 102070. [CrossRef]

37. Ball, R.; Brown, P. An Empirical Evaluation of Accounting Income Numbers. J. Account. Res. 1968, 6, 159. [CrossRef]

38. Fama, E.F.; Fisher, L.; Jensen, M.C.; Roll, R. The Adjustment of Stock Prices to New Information. Int. Econ. Rev. 1969, 10. [CrossRef] 
39. Wang, Y.-H.; Yang, F.-J.; Chen, L.-J. An investor's perspective on infectious diseases and their influence on market behavior. J. Bus. Econ. Manag. 2013, 14, S112-S127. [CrossRef]

40. Kuo, H.-I.; Chen, C.-C.; Tseng, W.-C.; Ju, L.-F.; Huang, B.-W. Assessing impacts of SARS and Avian Flu on international tourism demand to Asia. Tour. Manag. 2008, 29, 917-928. [CrossRef] [PubMed]

41. Keogh-Brown, M.R.; Smith, R. The economic impact of SARS: How does the reality match the predictions? Health Policy 2008, 88, 110-120. [CrossRef] [PubMed]

42. Page, S.; Yeoman, I.; Munro, C.; Connell, J.; Walker, L. A case study of best practice-Visit Scotland's prepared response to an influenza pandemic. Tour. Manag. 2006, 27, 361-393. [CrossRef]

43. Chen, M.-H. The response of hotel performance to international tourism development and crisis events. Int. J. Hosp. Manag. 2011, 30, 200-212. [CrossRef]

44. Chen, M.-H.; Kim, W.G.; Kim, H.J. The impact of macroeconomic and non-macroeconomic forces on hotel stock returns. Int. J. Hosp. Manag. 2005, 24, 243-258. [CrossRef]

45. Shaikh, I.; Huynh, T.L.D. Does disease outbreak news impact equity, commodity and foreign exchange market? Investors' fear of the pandemic COVID-19. J. Econ. Stud. 2021, in press. [CrossRef]

46. Dai, P.-F.; Xiong, X.; Liu, Z.; Huynh, T.L.D.; Sun, J. Preventing crash in stock market: The role of economic policy uncertainty during COVID-19. Financ. Innov. 2021, 7, 1-15. [CrossRef]

47. Huynh, T.L.D.; Foglia, M.; Nasir, M.A.; Angelini, E. Feverish sentiment and global equity markets during the COVID-19 pandemic. J. Econ. Behav. Organ. 2021, 188, 1088-1108. [CrossRef]

48. Mazur, M.; Dang, M.; Vega, M. COVID-19 and the march 2020 stock market crash. Evidence from S\&P1500. Financ. Res. Lett. 2020, 38, 101690. [CrossRef] [PubMed]

49. Goodell, J.W. COVID-19 and finance: Agendas for future research. Financ. Res. Lett. 2020, 35, 101512. [CrossRef] [PubMed]

50. Anh, D.L.T.; Gan, C. The impact of the COVID-19 lockdown on stock market performance: Evidence from Vietnam. J. Econ. Stud. 2021, 48, 836-851. [CrossRef]

51. Zoungrana, T.D.; Toé, D.L.T.; Toé, M. Covid-19 outbreak and stocks return on the West African Economic and Monetary Union's stock market: An empirical analysis of the relationship through the event study approach. Int. J. Financ. Econ. 2021. [CrossRef]

52. Ramelli, S.; Wagner, A.F. Feverish Stock Price Reactions to the Novel Coronavirus. SSRN Electron. J. 2020. [CrossRef]

53. Shahzad, S.J.H.; Bouri, E.; Kristoufek, L.; Saeed, T. Impact of the COVID-19 outbreak on the US equity sectors: Evidence from quantile return spillovers. Financ. Innov. 2021, 7, 1-23. [CrossRef]

54. Lin, B.; Su, T. Does COVID-19 open a Pandora's box of changing the connectedness in energy commodities? Res. Int. Bus. Financ. 2021, 56, 101360. [CrossRef]

55. Chiaramonti, D.; Maniatis, K. Security of supply, strategic storage and Covid19: Which lessons learnt for renewable and recycled carbon fuels, and their future role in decarbonizing transport? Appl. Energy 2020, 271, 115216. [CrossRef]

56. Kanda, W.; Kivimaa, P. What opportunities could the COVID-19 outbreak offer for sustainability transitions research on electricity and mobility? Energy Res. Soc. Sci. 2020, 68, 101666. [CrossRef]

57. Klemeš, J.J.; Van Fan, Y.; Jiang, P. COVID -19 pandemic facilitating energy transition opportunities. Int. J. Energy Res. 2021, 45, 3457-3463. [CrossRef] [PubMed]

58. Werth, A.; Gravino, P.; Prevedello, G. Impact analysis of COVID-19 responses on energy grid dynamics in Europe. Appl. Energy 2021, 281, 116045. [CrossRef]

59. Peter, J.; Wagner, J. Optimal Allocation of Variable Renewable Energy Considering Contributions to Security of Supply. Energy J. 2021, 42. [CrossRef]

60. Ye, S.; Dai, P.-F.; Nguyen, H.T.; Huynh, N.Q.A. Is the cross-correlation of EU carbon market price with policy uncertainty really being? A multiscale multifractal perspective. J. Environ. Manag. 2021, 298, 113490. [CrossRef]

61. Dai, P.-F.; Xiong, X.; Huynh, T.L.D.; Wang, J. The impact of economic policy uncertainties on the volatility of European carbon market. J. Commod. Mark. 2021, 100208. [CrossRef]

62. Wang, J.; Gu, F.; Liu, Y.; Fan, Y.; Guo, J. An Endowment Effect Study in the European Union Emission Trading Market based on Trading Price and Price Fluctuation. Int. J. Environ. Res. Public Health 2020, 17, 3343. [CrossRef] [PubMed]

63. Heffron, R.J.; Körner, M.-F.; Schöpf, M.; Wagner, J.; Weibelzahl, M. The role of flexibility in the light of the COVID-19 pandemic and beyond: Contributing to a sustainable and resilient energy future in Europe. Renew. Sustain. Energy Rev. 2021, $140,110743$. [CrossRef] [PubMed]

64. Zappa, W.; Junginger, M.; Broek, M.V.D. Can liberalised electricity markets support decarbonised portfolios in line with the Paris Agreement? A case study of Central Western Europe. Energy Policy 2021, 149, 111987. [CrossRef]

65. Petitet, M.; Finon, D.; Janssen, T. Capacity adequacy in power markets facing energy transition: A comparison of scarcity pricing and capacity mechanism. Energy Policy 2017, 103, 30-46. [CrossRef]

66. Gaddy, B.E.; Sivaram, V.; Jones, T.B.; Wayman, L. Venture Capital and Cleantech: The wrong model for energy innovation. Energy Policy 2017, 102, 385-395. [CrossRef]

67. Hain, M.; Schermeyer, H.; Uhrig-Homburg, M.; Fichtner, W. Managing renewable energy production risk. J. Bank. Financ. 2018, 97, 1-19. [CrossRef]

68. Grewal, J.; Riedl, E.J.; Serafeim, G. Market Reaction to Mandatory Nonfinancial Disclosure. Manag. Sci. 2019, 65, 3061-3084. [CrossRef] 
69. Porter, M.E.; Kramer, M.R. Creating Shared Value. Harv. Bus Rev. 2011, 89, 62-77.

70. Lundgren, T.; Olsson, R. How bad is bad news? Assessing the effects of environmental incidents on firm value. Am. J. Financ. Account. 2009, 1, 376. [CrossRef]

71. Cellier, A.; Chollet, P. The Impact of Corporate Social Responsibility Rating Announcement on Stock Prices: An Event Study on European Markets. Int. J. Bus. Soc. Sci. 2011, 11, 33.

72. Albuquerque, R.; Koskinen, Y.; Yang, S.; Zhang, C. Resiliency of Environmental and Social Stocks: An Analysis of the Exogenous COVID-19 Market Crash. Rev. Corp. Financ. Stud. 2020, 9, 593-621. [CrossRef]

73. Tampakoudis, I.; Noulas, A.; Kiosses, N.; Drogalas, G. The effect of ESG on value creation from mergers and acquisitions. What changed during the COVID-19 pandemic? Corp. Gov. Int. J. Bus. Soc. 2021, 21, 6. [CrossRef]

74. Dziadkowiec, A.; Daszynska-Zygadlo, K. Disclosures of ESG Misconducts and Market Valuations: Evidence from DAX Companies. Eng. Econ. 2021, 32, 95-103. [CrossRef]

75. Ahmar, A.S.; del Val, E.B. SutteARIMA: Short-term forecasting method, a case: Covid-19 and stock market in Spain. Sci. Total Environ. 2020, 729, 138883. [CrossRef] [PubMed]

76. Phan, D.H.B.; Narayan, P.K. Country Responses and the Reaction of the Stock Market to COVID-19-A Preliminary Exposition. Emerg. Mark. Financ. Trade 2020, 56, 2138-2150. [CrossRef]

77. Goodell, J.W.; Huynh, T.L.D. Did Congress trade ahead? Considering the reaction of US industries to COVID-19. Financ. Res. Lett. 2020, 36, 101578. [CrossRef] [PubMed]

78. Sandler, D.H.; Sandler, R. Multiple event studies in public finance and labor economics: A simulation study with applications. $J$. Econ. Soc. Meas. 2014, 39, 31-57. [CrossRef]

79. Fama, E.F.; French, K.R. Common risk factors in the returns on stocks and bonds. J. Financ. Econ. 1993, 33, 3-56. [CrossRef]

80. Liu, H.; Wang, Y.; He, D.; Wang, C. Short term response of Chinese stock markets to the outbreak of COVID-19. Appl. Econ. 2020, 52, 5859-5872. [CrossRef]

81. Liu, J.; Stambaugh, R.F.; Yuan, Y. Size and value in China. J. Financ. Econ. 2019, 134, 48-69. [CrossRef]

82. Takahashi, H.; Yamada, K. When the Japanese stock market meets COVID-19: Impact of ownership, China and US exposure, and ESG channels. Int. Rev. Financ. Anal. 2021, 74, 101670. [CrossRef]

83. González-Cruz, T.; Clemente-Almendros, J.A.; Puig-Denia, A. Family governance systems: The complementary role of constitutions and councils. Econ. Res. Ekon. Istraž. 2021, 1-25. [CrossRef]

84. Jiménez-Zarco, A.I.; Clemente-Almendros, J.A.; González-González, I.; Aracil-Jordà, J. Female Micro-Entrepreneurs and Social Networks: Diagnostic Analysis of the Influence of Social-Media Marketing Strategies on Brand Financial Performance. Front. Psychol. 2021, 12. [CrossRef] [PubMed]

85. Pérez-Luño, A.; Bojica, A.M.; Golapakrishnan, S. When more is less: The role of cross-functional. Int. J. Oper. Prod. Manag. 2019, 39, 94-115. [CrossRef]

86. Dawson, J.F.; Richter, A.W. Probing three-way interactions in moderated multiple regression: Development and application of a slope difference test. J. Appl. Psychol. 2006, 91, 917-926. [CrossRef] [PubMed]

87. Heavey, C.; Simsek, Z. Transactive Memory Systems and Firm Performance: An Upper Echelons Perspective. Organ. Sci. 2015, 26, 941-959. [CrossRef]

88. Hwang, J.; Kim, H.; Jung, D. The Effect of ESG Activities on Financial Performance during the COVID-19 Pandemic-Evidence from Korea. Sustainability 2021, 13, 11362. [CrossRef]

89. Garel, A.; Petit-Romec, A. The Resilience of French Companies to the COVID-19 Crisis. Finance 2021, 42, 99-137. [CrossRef]

90. Yen, T.-Y.; André, P. Market reaction to the effect of corporate social responsibility on mergers and acquisitions: Evidence on emerging markets. Q. Rev. Econ. Financ. 2019, 71, 114-131. [CrossRef] 